\title{
2 Differential utilization of biochemical components during 3 larval development of the spider crab Maja brachydactyla 4 (Decapoda: Majidae)
}

\author{
5 Mireia Andrés • Alicia Estévez • Francisco Hontoria • \\ 6 Guiomar Rotllant
}

7 Received: 19 April 2010/ Accepted: 17 June 2010

8 (C) Springer-Verlag 2010

9 Abstract Changes in lipid class, fatty acid, fat-soluble 10

vitamins, amino acid and minerals were studied during larval development of Maja brachydactyla Balss, 1922 in order to provide information of its ontogeny and evaluate possible dietary deficiencies and constraints. Four different batches were analyzed from hatching to metamorphosis using enriched Artemia as food. Cultured larvae were in a good nutritional condition as confirmed by the continuous lipid accumulation throughout ontogeny. A regulation of polyunsaturated fatty acids (PUFA) occurred during development in order to maintain adequate basal levels of $\omega$-3 fatty acids (likely through a retro conversion of $\mathrm{C}_{20}$ and $\mathrm{C}_{22}$ into $\mathrm{C}_{18}$ PUFA). Variations in the tocopherol levels indicated its possible role in PUFA protection against oxidation. Essential amino acid balance during development was not correlated with the Artemia feeding regime, but rather reflected inherent variations of the own species ontogeny. Larval requirements in essential minerals were fully supplied by the enriched Artemia.

\section{Communicated by X. Irigoien.}

M. Andrés ( $\square)$ · A. Estévez · G. Rotllant

IRTA Sant Carles de la Ràpita, Ctra. Poble Nou Km, 5.5.,

43540 Sant Carles de la Ràpita, Tarragona, Spain

e-mail: mireia.andres@gmail.com

\section{F. Hontoria}

Instituto de Acuicultura de Torre de la Sal (CSIC),

12595 Ribera de Cabanes, Castellón, Spain

\section{Introduction}

Survival and successful molting among planktotrophic larvae of brachyuran crabs is strongly dependent on the fulfillment of the nutritional requirements through their dietary input (Anger 2001). Larvae receiving optimal diets shorten the duration of larval development and settlement, increasing the recruitment success. The spider crab, Maja brachydactyla hatch as a zoea (zoea I, ZI) and must undergo two molts (zoea II, ZII and megalopa, M) and a metamorphosis before settling as first juvenile (crab I, C) (Guerao et al. 2008). In the wild, it is thought that spider crab zoeae display an opportunistic feeding behavior in which prey capture occurs by encounter probability. Larval potential preys include a whole range of particles that are present in the water column, ranging from dissolved organic matter, detritus and unicellular organisms (bacteria, protozoan and microalgae) to a great variety of metazoan (zooplankton) (Anger 2001). Diet of juveniles and adults of $M$. brachydactyla is assorted and basically omnivore, consisting mainly of macroalgae, molluscs and echinoderms (Bernárdez et al. 2000). Under culturing conditions, larvae of $M$. brachydactyla respond to the lipidenriched prey (enriched Artemia, EA) abundance through the accumulation of lipid reserves along their successive developmental stages (Andrés et al. 2008). The lipidenrichment of preys has been reported to improve development in brachyuran species (Urcera et al. 1993; Harvey and Epifanio 1997; Takeuchi et al. 1999; Rengel et al. 2000). On the other hand, it has been demonstrated that the essential fatty acid shortage promoted by an unenriched diet affects brachyuran larval development, causing prolonged intermolt periods and low survival (Suprayudi et al. 2004). Previous work on the optimization of M. brachydactyla larval culture showed that the increasing lipid

$\begin{array}{lll}\text { Journal : Large 227 } & \text { Dispatch : 25-6-2010 } & \text { Pages : 12 } \\ \text { Article No. : } \mathbf{1 4 9 9} & \square \text { LE } & \square \text { TYPESET } \\ \text { MS Code : MABI-D-10-00202 } & \sim_{\text {CP }} & \boldsymbol{L I S K}_{\text {DISK }}\end{array}$


reserves in the larvae promoted by the nutritional value of enriched Artemia induced a faster larval development (Andrés et al. 2007). It remains unclear what roles the essential fatty acids are playing during this process and whether an enriched-Artemia-based diet fulfills larval nutritional requirements or affects larval trophic condition.

Crustaceans, like other animals, need protein in the form of essential amino acids for maintenance of life, growth and reproduction, but the specific information concerning protein and amino acid nutrition is limited (Guillaume 1997). Environmental factors such as salinity and nutrition have been found to affect the amino acid composition in several crustacean species (Brucet et al. 2005), pointing out the need for an adequate amino acid balance for survival and growth, especially during early life stages. Furthermore, the role that other essential factors such as vitamins or minerals play during larval development is yet to be elucidated. Levels of amino acid, vitamins and minerals have been reported in newly hatched larvae of M. brachydactyla by Villanueva and colleagues (Villanueva et al. 2004; Villanueva and Bustamante 2006; Villanueva et al. 2009); however, no data is available concerning variations in further larval development.

Thus, the aim of the present study is to provide more exhaustive information in the ontogeny of the biochemical constituents of $M$. brachydactyla at early developmental stages in order to evaluate their physiologic condition and to detect possible dietary deficiencies and constraints that might affect the recruitment of this species.

\section{Materials and methods}

\section{Broodstock capture and maintenance}

Adult $M$. brachydactyla were captured with commercial fishery vessels of Galicia coasts, northwestern Spain, and transported to IRTA (Sant Carles de la Ràpita, Tarragona, Spain) by surface transport in high humidity containers around $8^{\circ} \mathrm{C}$. The broodstock was kept in 2,000-1 tanks connected to a recirculation unit (renewal rate $=65 \mathrm{~m}^{3}$ $\mathrm{h}^{-1}$ ) with constant salinity and temperature (36\%o, $18 \pm 1^{\circ} \mathrm{C}$ ), and fed with a combination of fresh mussels (Mytilus sp., five times per week) and frozen crab (Liocarcinus depurator, twice per week).

\section{Rearing of larvae}

Actively swimming larvae were collected from broodstock tanks within maximally ca. $12 \mathrm{~h}$ after hatching and subsequently transferred to 35-1 baskets provided with aeration (Andrés et al. 2007). Temperature and salinity were kept at constant $18 \pm 1{ }^{\circ} \mathrm{C}$ and $36 \%$, and natural photoperiod was used (ca. 12:12 h light: darkness; experiments carried out during early spring).

The initial rearing density was adjusted to 60 larvae per liter (2,100 larvae per basket). Lipid-enriched Artemia metanauplii (EA) were given as food every morning at a density of 60 nauplii larva $^{-1}$. Live prey density was adjusted daily by sampling and counting the Artemia nauplii that remained in the baskets, using volumetric procedures. The enrichment was obtained after 24-h incubation (36\% salinity, $25^{\circ} \mathrm{C}$ temperature) of newly hatched Artemia nauplii (250 nauplii $\mathrm{ml}^{-1}$, Enrichment Grade; INVE, Belgium) in a commercial product $\left(0.6 \mathrm{~g} \mathrm{l}^{-1}\right.$, EasySelco, INVE, Belgium).

Sampling and biometric measurements

Samples were taken on the day of hatching (ZI), and in ZII (7 \pm 1 days post-hatch, DPH), M $(11 \pm 1 \mathrm{DPH})$, and first juvenile crab I stage $(\mathrm{C}, 18 \pm 1 \mathrm{DPH})$, with the aim to sample the maximum number of representative individuals in the intermolt phase within the larval molting cycle (Guerao et al. 2010) and the newly metamorphosed juveniles. Variation by one day ( $\pm 1 \mathrm{DPH})$ in the timing of sampling reflects developmental variability among hatches. On each sampling day, 3 baskets (replicates) were removed from the tanks, while all other baskets remained in the experiment for later sampling. From the surviving larvae in each basket, 30 individuals were used to measure dry weight (DW); the rest was stored at $-80^{\circ} \mathrm{C}$ for later biochemical analyses. Thirty larvae (6 per replicate, $n=5)$ were gently rinsed in distilled water and blotted on a filter paper for wet-weight measurements. After 24-h oven-drying at $60^{\circ} \mathrm{C}$, DW was determined on a Sartorius BP211D (Sartorius, Germany) balance to the nearest $0.001 \mathrm{mg}$.

Lipid analyses (lipid class, fatty acid content and fat soluble vitamins) were carried out from 4 different batches belonging to different females to get 4 independent replicates (n) for every developmental stage, whereas for amino acid and mineral analyses pools of larvae belonging to different batches were used (see "Amino acid and mineral analysis").

Biochemical analysis

Lipid class and fatty acid analysis

Total lipid content (L) from developmental stages and enriched live food (EA) was quantified gravimetrically after extraction in chloroform/methanol (2:1) and evaporation of the solvent under a stream of nitrogen followed by vacuum desiccation overnight (Folch et al. 1957). Total lipids were stored $\left(10 \mathrm{mg} \mathrm{ml}^{-1}\right)$ in chloroform/ methanol (2:1 in volume) containing $0.01 \%$ butylated
153

154

155

156

157

158

$\begin{array}{lll}\text { Journal : Large 227 } & \text { Dispatch : 25-6-2010 } & \text { Pages : 12 } \\ \text { Article No. : } \mathbf{1 4 9 9} & \square \text { LE } & \square \text { TYPESET } \\ \text { MS Code : } \quad \text { MABI-D-10-00202 } & \sim_{\text {CP }} & \checkmark \text { DISK }\end{array}$


hydroxytoluene (BHT) at $-20^{\circ} \mathrm{C}$ for later lipid class and fatty acid analysis.

Lipid extracts resulting from the proximate analysis were used for the subsequent analysis of lipid class and fatty acid composition. Lipid class separation was performed by high-performance thin-layer chromatography (HPTLC) following the method by Olsen and Henderson (1989). After separation, bands were identified by charring the plates at $100^{\circ} \mathrm{C}$ for $30 \mathrm{~min}$ after spraying with $3 \%(\mathrm{w} / \mathrm{v})$ aqueous cupric acetate containing $8 \%(\mathrm{v} / \mathrm{v})$ phosphoric acid and quantified by scanning densitometry using a GS 800 Calibrated Densitometer (Bio-Rad, Bio-Rad Laboratories, Inc, Hercules, CA, USA).

Fatty acid methyl esters (FAME) were prepared from total lipid by acid-catalyzed transmethylation using $2 \mathrm{ml}$ of $1 \% \mathrm{H}_{2} \mathrm{SO}_{4}$ in methanol plus $1 \mathrm{ml}$ toluene (Christie 1982) and thereafter extracted twice using isohexane/diethyl ether (1:1, v:v) (Ghioni et al. 2002) and purified on TLC plates. FAME were separated and quantified by gas-liquid chromatography on a Trace GC (Thermo, Thermo Fisher Scientific Inc., Waltham, MA, USA) using a flame ionization detector and on column injection. Individual methyl esters were identified by comparison to known standards (Supelco 37 FAME mix 47885-U) and a well-characterized fish oil, and quantified by means of the response factor to the internal standard 21:0 fatty acid, added prior to transmethylation, using a Chrompack for Windows program (Thermo Electron, Winsford, UK).

\section{Fat soluble vitamins}

Retinoid and tocopherol content on larvae and juvenile crabs were analyzed by HPLC, using a modification of the method proposed by Takeuchi et al. (1998). Lipids were extracted with a chloroform:methanol mixture (C:M, 2:1) according to the Folch method (Folch et al. 1957) and stored in C:M:BHT $(2: 1: 0.01)$ at $20 \mathrm{mg}^{-1}$ and $-20^{\circ} \mathrm{C}$ until their analysis. Then, samples were evaporated and redissolved on methanol:acetone $(1: 1 \mathrm{v} / \mathrm{v})$ prior to their HPLC analysis. The HPLC system (Thermo Separation Products, San Jose, CA, USA) was equipped with a Lichrospher C-18 reverse phase column (Merck, Darmstadt, Germany) and a UV-visible photodiode array detector set at wavelengths of 284 and $325 \mathrm{~nm}$ to track tocopherol and retinoid peaks, respectively. The mobile phase was a mixture $(85: 15 \mathrm{v} / \mathrm{v})$ of methanol $(98 \%)$ with $0.5 \%$ ammonium acetate, and chloroform. The flow rate was $1.5 \mathrm{ml} \mathrm{min}^{-1}$, and the elution time was $18 \mathrm{~min}$. The concentration of each retinoid or $\alpha$-tocopherol was calculated from the calibration curves constructed with the peak area ratios of their external standards and internal standards of retinol acetate and tocopherol acetate, respectively, added to the samples. All the reference retinoids and tocopherols were purchased from SigmaAldrich (Spain).

\section{Amino acid and mineral analysis}

Due to the large amount of material required, total amino acid (AA, except tryptophan) and mineral analyses were performed after pooling samples of larvae and first juveniles in the same developmental stage belonging to different batches and was carried out by an external laboratory (OFICE, S. L., Barcelona, Spain). Amino acid content was analyzed by HPLC-fluorescence based on the methods by Davies and Thomas (1973) and Pfeifer et al. (1983). Amino acid profiles of enriched Artemia used for comparison of the essential amino acid profiles between $M$. brachydactyla developmental stages and their prey were extracted from Villanueva et al. (2004), considering that the enrichment process and products used in Villanueva and colleagues' work are comparable to those described in the present study. The analyses of $\mathrm{Na}, \mathrm{K}, \mathrm{Ca}, \mathrm{Fe}, \mathrm{Cu}, \mathrm{Mg}$ and $\mathrm{Mn}$ were performed by atomic absorption spectrophotometry (AAS) following the official methods of AOAC International (AOAC 2005a, b, c, d, e, g). P was analyzed spectrophotometrically (AOAC 2005f), and $\mathrm{Sr}$ was estimated by inductively coupled plasma (ICP) analysis.

Statistical analysis

The statistical treatment of the data was performed using a SigmaPlot 9 and a SigmaStat 3 (Systat Software Inc., USA) software packages. Differences in biochemical composition between stages were tested by one-way ANOVA analysis (data normally distributed, Kolmogorov-Smirnov test, no transformations applied). Comparisons between groups after finding significant differences were performed by Holm-Sidak test with an overall significance level of $P<0.05$. Essential amino acid profiles of $M$. brachydactyla developmental stages and enriched Artemia were compared by means of Student 's $t$-test $(P<0.05)$.

\section{Results}

Lipids

Despite the lipid-enriched prey provided $(\mathrm{EA}=20.2 \% \overline{\bar{\nu}} 247$ $\mathrm{DW}^{-1}$ ) (Table 1), the lipid content of $M$. brachydactyla 248 larval stages did not change significantly during development. Neutral lipids were the main components of the lipid class composition in all developmental stages analyzed, accounting for $72.4 \%$ of total lipids in newly hatched ZI

$\begin{array}{lll}\text { Journal : Large 227 } & \text { Dispatch : 25-6-2010 } & \text { Pages : 12 } \\ \text { Article No. : } \mathbf{1 4 9 9} & \square \text { LE } & \square \text { TYPESET } \\ \text { MS Code : MABI-D-10-00202 } & \boldsymbol{V}_{\text {CP }} & \checkmark \text { DISK }\end{array}$


Table 1 Individual dry weight (DW), lipid (L) content and lipid class composition $\left(\mu \mathrm{g} \mathrm{mg} \mathrm{DW} \mathrm{DW}^{-1}\right)$ during larval development (zoea I = ZI; zoea II = ZII and megalopa $=\mathrm{M}$ ) and first juvenile stage (C) of M. brachydactyla and enriched metanauplii of Artemia sp. (EA)

\begin{tabular}{|c|c|c|c|c|c|}
\hline & ZI & ZII & M & $\mathrm{C}$ & EA \\
\hline DW $(\mu \mathrm{g})$ & $94 \pm 14^{\mathrm{a}}$ & $190 \pm 22^{\mathrm{b}}$ & $392 \pm 39^{c}$ & $617 \pm 46^{\mathrm{d}}$ & \\
\hline$\% \mathrm{~L}$ & $4.9 \pm 1.1$ & $5.9 \pm 0.8$ & $6.9 \pm 1.6$ & $6.8 \pm 2.9$ & 20.2 \\
\hline Total polar & $13.6 \pm 3.9$ & $14.3 \pm 2.6$ & $14.4 \pm 4.5$ & $12.2 \pm 4.7$ & 30.4 \\
\hline Sphingomyelin & $0.0 \pm 0.0$ & $0.1 \pm 0.2$ & $0.2 \pm 0.2$ & $0.3 \pm 0.3$ & 0.0 \\
\hline Phosphatidylcholine & $6.7 \pm 2.0$ & $6.6 \pm 1.5$ & $6.6 \pm 2.0$ & $5.7 \pm 2.7$ & 13.1 \\
\hline Phosphatidylserine & $0.7 \pm .02$ & $0.7 \pm 0.2$ & $0.6 \pm 0.3$ & $0.5 \pm 0.3$ & 1.5 \\
\hline Phosphatidylinositol & $1.2 \pm 0.5$ & $1.1 \pm 0.2$ & $1.3 \pm 0.5$ & $0.8 \pm 0.1$ & 2.7 \\
\hline Phosphatidic acid/Cardiolopin & $0.3 \pm 0.4$ & $0.7 \pm 0.1$ & $0.7 \pm 0.2$ & $0.7 \pm 0.2$ & 0.0 \\
\hline Phosphatidylethanolamine & $4.8 \pm 2.2$ & $5.1 \pm 0.8$ & $5.0 \pm 1.3$ & $4.3 \pm 2.2$ & 13.1 \\
\hline Total neutral & $35.7 \pm 10.8$ & $45.2 \pm 9.6$ & $54.4 \pm 14.9$ & $56.0 \pm 24.5$ & 171.3 \\
\hline Cholesterol & $14.5 \pm 4.1$ & $13.3 \pm 2.4$ & $13.5 \pm 2.5$ & $16.0 \pm 5.8$ & 16.4 \\
\hline Free fatty acids & $0.0 \pm 0.0$ & $0.5 \pm 0.4$ & $1.9 \pm 1.8$ & $2.1 \pm 1.9$ & 7.2 \\
\hline Triacylglycerols & $5.7 \pm 5.8$ & $13.2 \pm 6.0$ & $23.1 \pm 9.3$ & $17.9 \pm 14.7$ & 93.6 \\
\hline Sterol esters/waxes & $15.5 \pm 5.6$ & $18.2 \pm 6.7$ & $15.8 \pm 6.4$ & $20.0 \pm 6.8$ & 54.1 \\
\hline
\end{tabular}

Data is shown as mean \pm SD (number of replicates: $n=4$, see "Sampling and biometric measurements" in text for details). Different letters in superscripts within the same row denote significant differences among developmental stages (ANOVA, Holm-Sidak test, $P<0.05$ )

and up to $82.11 \%$ in C. Neutral lipid reserves increased mainly in the form of triacylglycerols (TG) during the larval phase, whereas in juveniles, the major increase corresponded to the waxes and sterol esters fraction (SE/W). Cholesterol (CHO) represented an important fraction, with steady levels around $15 \mu \mathrm{g} \mathrm{mg} \mathrm{DW}^{-1}$ throughout larval development and first juvenile. During M. brachydactyla development, the major phospholipids were phosphatidylcholine (PC) and phosphatidylethanolamine (PE), although significant amounts of phosphatidylinositol (PI), phosphatidylserine (PS), phosphatidic acid/cardiolopin (PA/ $\mathrm{CL}$ ) and sphingomyelin (SM) were also found. No significant changes were detected in the phospholipid content of the larvae as development advanced.

Total saturated fatty acid (SFA) content did not change significantly during development, despite the relative high content in EA ( $\left.23.3 \mu \mathrm{g} \mathrm{mg} \mathrm{DW}^{-1}\right)$ (Table 2). The monounsaturated oleic acid (OA, 18:1n-9) increased significantly during larval development, reaching its maximum in $\mathrm{M}\left(10.5 \pm 4.2 \mu \mathrm{g} \mathrm{mg} \mathrm{DW}^{-1}\right)$ and slightly decreasing at first juvenile. In the case of polyunsaturated $\omega-6$ family (PUFA n-6), linoleic acid (LA, 18:2n-6) increased from ZI $\left(0.4 \pm 0.1 \mu \mathrm{g} \mathrm{mg} \mathrm{DW}^{-1}\right)$ to $\mathrm{M}$ and $\mathrm{C}(3.9 \pm 1.6$ and $3.0 \pm 1.5 \mu \mathrm{g} \mathrm{mg} \mathrm{DW}^{-1}$, respectively), whereas no significant changes were found in arachidonic acid (ARA, 20:4n6), the levels of which were maintained around $1.0 \mu \mathrm{g} \mathrm{mg}$ $\mathrm{DW}^{-1}$, similarly to those found in the EA. Overall, total PUFA $\mathrm{n}-6$ increased up to $\mathrm{M}\left(5.5 \pm 2.1 \mu \mathrm{g} \mathrm{mg} \mathrm{DW}^{-1}\right)$ and decreased slightly in C. Within the essential $\omega-3$ PUFA, eicosapentaenoic acid (EPA, 20:5n-3) was the most representative FA in $M$. brachydactyla early life stages, showing no significant level change along larval development $\left(\mathrm{ZI}=6.6 \pm 1.4 \mu \mathrm{g} \mathrm{mg} \mathrm{DW}^{-1} ; \quad \mathrm{M}=6.9 \pm 2.8\right.$ $\left.\mu \mathrm{g} \mathrm{mg} \mathrm{DW}{ }^{-1}\right)$ or after metamorphosis $(\mathrm{C}=4.8 \pm 1.7$ $\mu \mathrm{g} \mathrm{mg} \mathrm{DW}{ }^{-1}$ ). Docosahexaenoic acid (DHA, 22:6n-3) levels dropped significantly after ZI and remained constant thereafter, despite the high levels of DHA found in EA $\left(4.0 \mu \mathrm{g} \mathrm{mg} \mathrm{DW}^{-1}\right)$. As a consequence, EPA/DHA ratio increased significantly during larval development and dropped after metamorphosis to $C$, whereas $n-3 / n-6$ ratio decreased significantly after ZI and remained constant during the rest of larval development and $\mathrm{C}$.

Fat-soluble vitamins

Vitamin E ( $\alpha$-tocopherol) and A (retinoids) levels are shown in Fig. 1. Tocopherol decreased from ZI $\left(333.8 \pm 167.0 \mathrm{ng} \mathrm{mg} \mathrm{DW}^{-1}\right)$ onward, reaching its minimum in $\mathrm{C}\left(161.8 \pm 65.7 \mathrm{ng} \mathrm{mg} \mathrm{DW}^{-1}\right)$. On the other hand, the different components of the retinoid family showed distinct patterns of variation throughout the ontogeny. The major component of the family during larval development was retinol, which showed its maximum level in ZII $\left(0.8 \pm 0.3 \mathrm{ng} \mathrm{mg} \mathrm{DW}^{-1}\right)$. Significant levels of retinyl palmitate were also found during larval development, whereas only trace levels of retinoic acid were detected. The metamorphosis onto first juvenile implied a significant increase in retinoic acid (up to $0.6 \pm 0.4 \mathrm{ng} \mathrm{mg} \mathrm{DW}^{-1}$ ), being the main component of the retinoid family in this stage, and a drop in the levels of both retinol $(0.4 \pm 0.2$ ng $\left.\mathrm{mg} \mathrm{DW}^{-1}\right)$ and retinyl palmitate $(0.2 \pm 0.2 \mathrm{ng} \mathrm{mg}$ $\left.\mathrm{DW}^{-1}\right)$. 
Table 2 Changes in individual dry weight (DW), lipid (L) and fatty acid (FA) content and main FA profile $\left(\mu \mathrm{g} \mathrm{FA} \mathrm{mg} \mathrm{DW}{ }^{-1}\right)$ during larval development (zoea I = ZI; zoea II = ZII and megalopa $=$ M) and first juvenile stage (C) of $M$. brachydactyla and enriched metanauplii of Artemia sp. (EA)

\begin{tabular}{|c|c|c|c|c|c|}
\hline & $\mathrm{ZI}$ & ZII & M & $\mathrm{C}$ & EA \\
\hline $\mathrm{DW}(\mu \mathrm{g})$ & $94 \pm 14^{\mathrm{a}}$ & $190 \pm 22^{b}$ & $392 \pm 39^{c}$ & $617 \pm 46^{\mathrm{d}}$ & \\
\hline$\% \mathrm{~L}$ & $4.9 \pm 1.1$ & $5.9 \pm 0.8$ & $6.9 \pm 1.6$ & $6.8 \pm 2.9$ & 20.2 \\
\hline$\mu \mathrm{g} \mathrm{FA} \mathrm{mg} \mathrm{L}{ }^{-1}$ & $594 \pm 198$ & $709 \pm 37$ & $761 \pm 178$ & $655 \pm 60$ & 664 \\
\hline $16: 0$ & $3.9 \pm 0.5$ & $5.2 \pm 0.9$ & $6.0 \pm 2.3$ & $5.3 \pm 2.9$ & 14.7 \\
\hline 18:0 & $3.1 \pm 0.6$ & $3.3 \pm 0.3$ & $3.7 \pm 0.9$ & $3.5 \pm 1.7$ & 7.4 \\
\hline $\mathrm{SFA}^{1}$ & $7.3 \pm 1.0$ & $9.0 \pm 1.3$ & $10.3 \pm 3.3$ & $9.4 \pm 4.8$ & 23.3 \\
\hline $16: 1$ & $2.1 \pm 0.1$ & $2.7 \pm 0.4$ & $3.7 \pm 1.7$ & $2.7 \pm 1.2$ & 7.8 \\
\hline $18: 1 n-9$ & $2.8 \pm 0.3^{\mathrm{a}}$ & $7.4 \pm 1.2^{\mathrm{ab}}$ & $10.5 \pm 4.2^{\mathrm{b}}$ & $10.1 \pm 5.9^{\mathrm{ab}}$ & 29.5 \\
\hline MUFA $^{2}$ & $7.0 \pm 0.4$ & $14.7 \pm 2.1$ & $20.6 \pm 9.0$ & $17.8 \pm 9.4$ & 48.8 \\
\hline $18: 2 n-6$ & $0.4 \pm 0.1^{\mathrm{a}}$ & $2.5 \pm 0.3^{\mathrm{ab}}$ & $3.9 \pm 1.6^{\mathrm{b}}$ & $3.0 \pm 1.5^{\mathrm{b}}$ & 11.1 \\
\hline $20: 4 n-6$ & $1.3 \pm 0.2$ & $0.9 \pm 0.1$ & $1.1 \pm 0.4$ & $0.7 \pm 0.3$ & 0.7 \\
\hline PUFA $n-6^{3}$ & $2.1 \pm 0.4^{\mathrm{a}}$ & $3.8 \pm 0.3^{\mathrm{ab}}$ & $5.5 \pm 2.1^{\mathrm{b}}$ & $4.0 \pm 1.9^{\mathrm{ab}}$ & 12.3 \\
\hline $18: 3 n-3$ & $0.0 \pm 0.0^{\mathrm{a}}$ & $5.2 \pm 1.6^{\mathrm{ab}}$ & $6.7 \pm 3.9^{\mathrm{b}}$ & $5.0 \pm 2.8^{\mathrm{ab}}$ & 30.5 \\
\hline $20: 5 n-3$ & $6.6 \pm 1.4$ & $5.7 \pm 0.3$ & $6.9 \pm 2.8$ & $4.8 \pm 1.7$ & 7.2 \\
\hline $22: 6 n-3$ & $4.3 \pm 0.7^{\mathrm{b}}$ & $2.4 \pm 0.3^{\mathrm{a}}$ & $2.4 \pm 0.8^{\mathrm{a}}$ & $2.8 \pm 1.1^{\mathrm{ab}}$ & 4.0 \\
\hline EPA/DHA & $1.55 \pm 0.2^{\mathrm{a}}$ & $2.4 \pm 0.2^{\mathrm{bc}}$ & $2.8 \pm 0.5^{\mathrm{c}}$ & $1.7 \pm 0.2^{\mathrm{ab}}$ & 1.78 \\
\hline PUFA n- $3^{4}$ & $11.5 \pm 2.0$ & $14.3 \pm 1.5$ & $17.4 \pm 7.9$ & $13.7 \pm 6.0$ & 49.6 \\
\hline Total PUFA ${ }^{5}$ & $14.0 \pm 2.3$ & $18.5 \pm 1.6$ & $23.5 \pm 10.1$ & $18.1 \pm 8.0$ & 63.5 \\
\hline$n-3 / n-6$ & $5.49 \pm 1.0^{\mathrm{b}}$ & $3.8 \pm 0.3^{\mathrm{a}}$ & $3.2 \pm 0.5^{\mathrm{a}}$ & $3.5 \pm 0.2^{\mathrm{a}}$ & 4.02 \\
\hline
\end{tabular}

Data is shown as mean \pm SD (number of replicates: $n=4$, see "Sampling and biometric measurements" in text for details). Different letters in superscripts within the same row denote significant differences among developmental stages (ANOVA, Holm-Sidak test, $P<0.05$ )

${ }^{1}$ SFA (Saturated FA): sum of 14:0, 16:0, 18:0, 20:0 and 22:0. ${ }^{2}$ MUFA (Monounsaturated FA): sum of 16:1, 18:1, 20:1 and 22:1. ${ }^{3}$ PUFA n - 6 (Polyunsaturated FA $\omega-6$ ): sum of 18:2n $-6,18: 3 n-6,20: 3 n-6,20: 4 n-6,22: 5 n-6 .{ }^{4}$ PUFA $n-3$ (Polyunsaturated FA $\omega-3$ ): sum of $18: 3 n-3,18: 4 n-3,20: 4 n-3,20: 5 n-3,22: 4 n-3,22: 5 n-3,22: 6 n-3 .^{5}$ TOTAL PUFA sum of 16:2, 16:3, 16:4, n - 3 and $n-6$

\section{Amino acids}

A dramatic shift in the essential AA composition occurred during ontogeny (Table 3). In newly hatched larvae, Leu, Lys, Val and Thr were the main essential AA (accounting for $34.9 \pm 0.0,34.9 \pm 0.0,27.8 \pm 0.9$ and $26.0 \pm 0.0$ $\mu \mathrm{g} \mathrm{mg} \mathrm{DW}{ }^{-1}$, respectively), whereas Arg became the main essential in juveniles $\left(32.0 \pm 0.0 \mu \mathrm{g} \mathrm{mg} \mathrm{DW}{ }^{-1}\right)$ after a high and significant drop in the others, especially in Thr and Lys that were reduced in more than $40 \%$ their initial content. The rest of the essential AA (EAA) varied in a lesser scale during larval development and decreased significantly in the first juvenile. In the case of non-essential AAs, a significant decrease in Glu, Ala and Gly was observed in juveniles, especially Glu which was reduced to half its initial content. Peaks in Pro and Tyr were observed in ZII $\left(35.1 \pm 0.0 \mu \mathrm{g} \mathrm{mg} \mathrm{DW}{ }^{-1}\right.$ and $16.6 \pm 1.1 \mu \mathrm{g} \mathrm{mg}$ $\mathrm{DW}^{-1}$, respectively), and a significant increase in Asp and Ser was detected from ZII onward. Comparisons between the EAA profiles of larval and first juvenile stages of $M$. brachydactyla versus EAA profiles of their prey, enriched Artemia (EA, data extracted from Villanueva et al.
2004) are shown in Fig. 2. Newly hatched larvae (ZI) of $M$. brachydactyla contained significantly higher levels of Leu, Val and Thr than EA. As larval development advanced, both Leu and Val levels kept significantly higher in the larvae (ZII and M) than in their prey; however, levels of Thr decreased in the larvae, tending to match EA levels. After metamorphosis (C), Val content continued to be higher in $M$. brachydactyla than in the live food, concomitant with a high increase in Arg levels, which represented near $21 \%$ of total EAA profile of $\mathrm{C}$ in contrast to $15 \%$ total EAA reported for EA (Fig. 2).

Mineral content

Calcium was the most abundant mineral during $M$. brachydactyla ontogeny (Table 4) with constant levels maintained in the larval stages (around $90 \mathrm{~g} \mathrm{Ca} \mathrm{kg} \mathrm{DW}^{-1}$ ) and a dramatic increase in juveniles $(173.94 \pm 6.46 \mathrm{~g} \mathrm{Ca}$ $\mathrm{kg} \mathrm{DW}^{-1}$ ). Na and $\mathrm{K}$ showed the same decreasing pattern throughout larval stages showing a minimum level in $\mathrm{M}$ $\left(23.20 \pm 0.00 \mathrm{~g} \mathrm{~kg} \mathrm{DW}^{-1}\right.$ and $16.11 \pm 0.00 \mathrm{~g} \mathrm{~kg} \mathrm{DW}^{-1}$, respectively), although in juveniles Na levels increased and

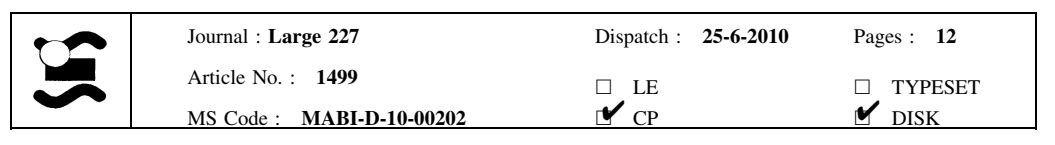



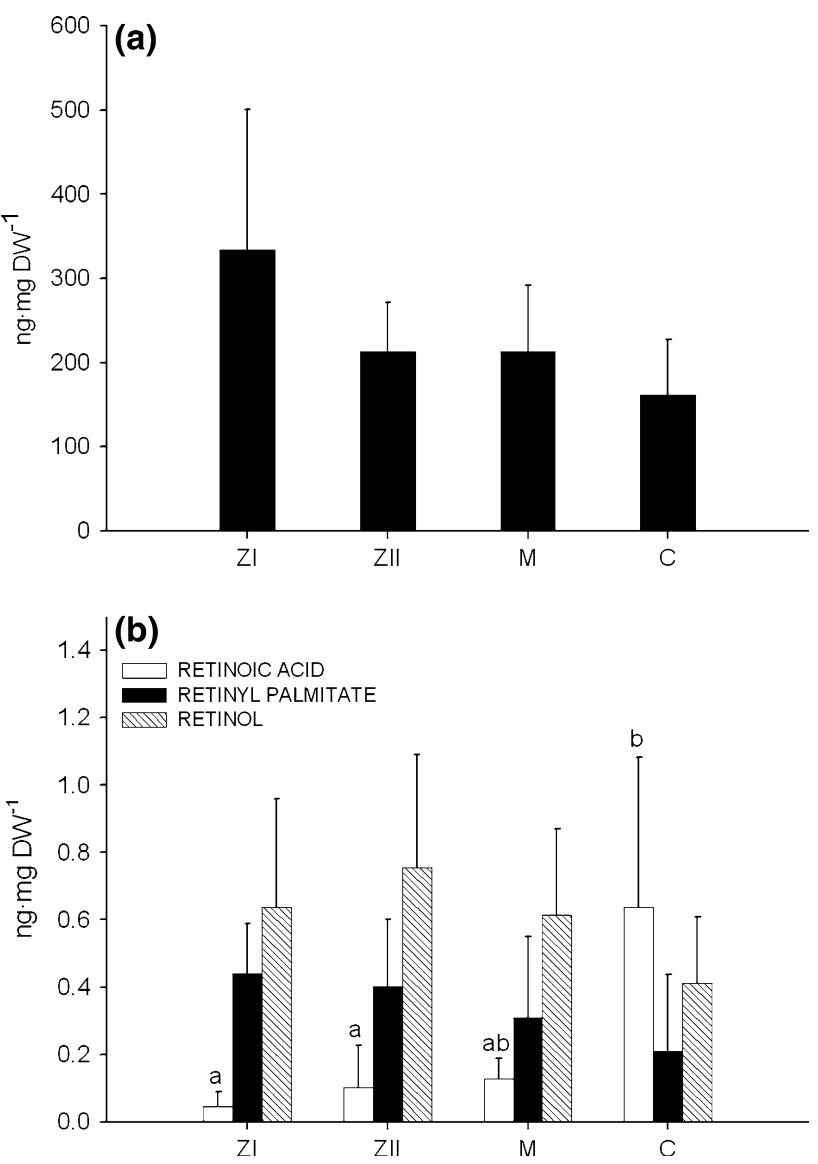

Fig. 1 Fat-soluble vitamin content: $\mathbf{a} \alpha$-tocopherol and $\mathbf{b}$ retinoids (retinol, retinoic acid and retinyl palmitate) during larval development (zoea $\mathrm{I}=\mathrm{ZI}$; zoea $\mathrm{II}=\mathrm{ZII}$ and megalopa $=\mathrm{M}$ ) and first juvenile stage (C) of $M$. brachydactyla. Data is shown as mean \pm SD (number of replicates: $n=4$, see "Sampling and biometric measurements" in text for details). Different letters in superscripts within the bars denote significant differences among developmental stages (ANOVA, Holm-Sidak test, $P<0.05$ )

354

355

356

357

358

359

360

361

362

363

364

365

366

367

368
$\mathrm{K}$ decreased. $\mathrm{P}, \mathrm{Mg}$ and $\mathrm{Sr}$ levels showed no significant differences along larval development. Metamorphosis implied a decrease in P levels and an increase in $\mathrm{Mg}$ and Sr. Iron showed an irregular pattern of decreasing and increasing values with maximum levels in $M$ $\left(0.125 \pm 0.001 \mathrm{~g} \mathrm{Fe} \mathrm{kg} \mathrm{DW}^{-1}\right)$. On the other hand, $\mathrm{Cu}$ dropped after first molt and kept constant afterward, while $\mathrm{Mn}$ levels increased after metamorphosis (up to $0.018 \pm 0.002 \mathrm{~g} \mathrm{~kg} \mathrm{DW}^{-1}$ ).

\section{Discussion}

Total lipid variations during larval development of $M$. brachydactyla have been previously described by Andrés et al. (2008) being in accordance with the results presented here. Both studies show an increasing trend in lipid content as larval ontogeny advances due to the effect of
Table 3 Total amino acid content ( $\mu \mathrm{g}$ AA mg DW ${ }^{-1}$ ) during larval development (zoea $\mathrm{I}=\mathrm{ZI}$; zoea $\mathrm{II}=\mathrm{ZII}$ and megalopa $=\mathrm{M}$ ) and first juvenile stage (C) of $M$. brachydactyla

\begin{tabular}{|c|c|c|c|c|}
\hline & ZI & ZII & M & $\mathrm{C}$ \\
\hline \multicolumn{5}{|l|}{ EAA } \\
\hline Leu & $34.9 \pm 0.0^{\mathrm{bc}}$ & $35.6 \pm 0.4^{\mathrm{c}}$ & $33.9 \pm 0.7^{\mathrm{b}}$ & $24.2 \pm 1.0^{\mathrm{a}}$ \\
\hline Lys & $34.9 \pm 0.0^{\mathrm{c}}$ & $26.6 \pm 1.1^{\mathrm{b}}$ & $22.6 \pm 2.3^{\mathrm{a}}$ & $20.7 \pm 2.0^{\mathrm{a}}$ \\
\hline Val & $27.8 \pm 0.9^{\mathrm{b}}$ & $28.5 \pm 0.0^{\mathrm{b}}$ & $27.5 \pm 0.4^{b}$ & $21.0 \pm 0.6^{\mathrm{a}}$ \\
\hline Thr & $26.0 \pm 0.0^{\mathrm{d}}$ & $20.9 \pm 0.8^{c}$ & $19.8 \pm 0.4^{\mathrm{b}}$ & $13.3 \pm 0.6^{\mathrm{a}}$ \\
\hline Ile & $20.9 \pm 1.0^{\mathrm{b}}$ & $22.2 \pm 0.4^{\mathrm{b}}$ & $20.8 \pm 0.4^{\mathrm{b}}$ & $14.5 \pm 0.0^{\mathrm{a}}$ \\
\hline Phe & $18.8 \pm 0.0^{\mathrm{bc}}$ & $19.0 \pm 0.0^{c}$ & $18.5 \pm 0.4^{\mathrm{b}}$ & $14.5 \pm 0.0^{\mathrm{a}}$ \\
\hline Arg & $17.0 \pm 0.0^{\mathrm{a}}$ & $15.3 \pm 0.0^{\mathrm{b}}$ & $24.1 \pm 0.4^{\mathrm{c}}$ & $32.0 \pm 0.0^{\mathrm{d}}$ \\
\hline His & $11.0 \pm 0.5^{\mathrm{bc}}$ & $11.7 \pm 0.0^{\mathrm{c}}$ & $10.7 \pm 0.4^{b}$ & $8.1 \pm 0.3^{\mathrm{a}}$ \\
\hline Met & $4.6 \pm 0.1^{\mathrm{a}}$ & $8.3 \pm 0.8^{b}$ & $7.9 \pm 0.7^{b}$ & $5.0 \pm 0.2^{\mathrm{a}}$ \\
\hline \multicolumn{5}{|c|}{ NEAA } \\
\hline Glu & $68.6 \pm 0.5^{\mathrm{bc}}$ & $73.8 \pm 1.5^{\mathrm{d}}$ & $70.2 \pm 1.7^{\mathrm{c}}$ & $34.6 \pm 0.6^{\mathrm{a}}$ \\
\hline Ala & $46.0 \pm 1.4^{\mathrm{d}}$ & $48.0 \pm 0.8^{c}$ & $41.0 \pm 0.4^{\mathrm{b}}$ & $35.0 \pm 1.0^{\mathrm{a}}$ \\
\hline Gly & $42.4 \pm 1.0^{\mathrm{b}}$ & $42.6 \pm 0.4^{\mathrm{b}}$ & $41.0 \pm 0.7^{\mathrm{b}}$ & $29.7 \pm 1.1^{\mathrm{a}}$ \\
\hline Pro & $19.7 \pm 0.0^{\mathrm{b}}$ & $35.1 \pm 0.0^{c}$ & $20.4 \pm 0.7^{\mathrm{b}}$ & $16.2 \pm 0.6^{\mathrm{a}}$ \\
\hline Asp & $13.4 \pm 0.0^{\mathrm{b}}$ & $11.9 \pm 0.4^{\mathrm{a}}$ & $16.1 \pm 0.0^{\mathrm{c}}$ & $19.7 \pm 0.6^{\mathrm{d}}$ \\
\hline Tyr & $10.7 \pm 0.0^{\mathrm{b}}$ & $16.6 \pm 1.1^{\mathrm{d}}$ & $12.9 \pm 0.0^{c}$ & $5.4 \pm 0.1^{\mathrm{a}}$ \\
\hline Ser & $5.8 \pm 0.1^{b c}$ & $5.0 \pm 0.2^{\mathrm{a}}$ & $6.1 \pm 0.1^{\mathrm{c}}$ & $9.0 \pm 0.6^{\mathrm{d}}$ \\
\hline Cys & $2.7 \pm 0.0^{c}$ & $2.2 \pm 0.0^{\mathrm{a}}$ & $2.5 \pm 0.0^{\mathrm{b}}$ & $2.9 \pm 0.0^{\mathrm{d}}$ \\
\hline
\end{tabular}

Data is shown as mean $\pm \mathrm{SD}$ (number of replicates: $n=3$, see "Sampling and biometric measurements" in text for details)

Different letters in superscript within the same row indicate significant differences among developmental stages (ANOVA, Holm-Sidak test, $P<0.05$ )

$E A A$ essential amino acids, NEAA non essential amino acids

feeding enriched Artemia nauplii which would have allowed for a continued lipid accumulation reaching its maximum at M stage. Artemia enrichment has been demonstrated to promote an increase in the lipid stores of larvae in M. brachydactyla (Andrés et al. 2007) and Scylla serrata (Suprayudi et al. 2004). Lipid accumulation throughout larval development of the spider crab was accompanied by an increase in neutral lipid reserves mainly in the form of TG during larval development and SE/W in the juveniles. TG content in the larvae can be used as a condition index potentially governing survival and success at metamorphosis (Fraser 1989; Ouellet et al. 1992), being considered the prevalent short-term lipid reserve mobilized for energy in many marine organisms. On the other hand, waxes (W) have been regarded as long-term lipid stores, having a higher energetic value than other storage lipids. Large stores of $\mathrm{W}$ are characteristic of many planktonic invertebrates such as copepods (Auel et al. 2002) being synthesized in preference to TG by marine invertebrates when food supply is irregular or seasonal and which consequently must make maximum use of food when it becomes available (Sargent 1976). Neutral lipid accumulation throughout

\begin{tabular}{|l|lll|}
\hline & Journal : Large 227 & Dispatch : 25-6-2010 & Pages : 12 \\
Article No. : 1499 & $\square_{\text {LE }}$ & $\square$ TYPESET \\
MS Code : MABI-D-10-00202 & $\checkmark_{\text {CP }}$ & $\checkmark$ DISK \\
\hline
\end{tabular}


Fig. 2 Comparison of the essential amino acid (EAA) profiles (\%) of

M. brachydactyla

developmental stages (zoea

$\mathrm{I}=\mathrm{ZI}$; zoea II = ZII;

megalopa $=\mathrm{M}$ and first

juvenile $=\mathrm{C}$ ) and the EAA profiles of enriched Artemia (EA, data from Villanueva et al. 2004). Points above the line of slope 1 and intercept 0 suggest deficiencies for that amino acid in the live food. Amino acids with significantly different levels in $M$. brachydactyla and its prey are indicated $(*)$ (Student $T$-test; $P<0.05, n=3$ see "Sampling and biometric measurements" in text for details)
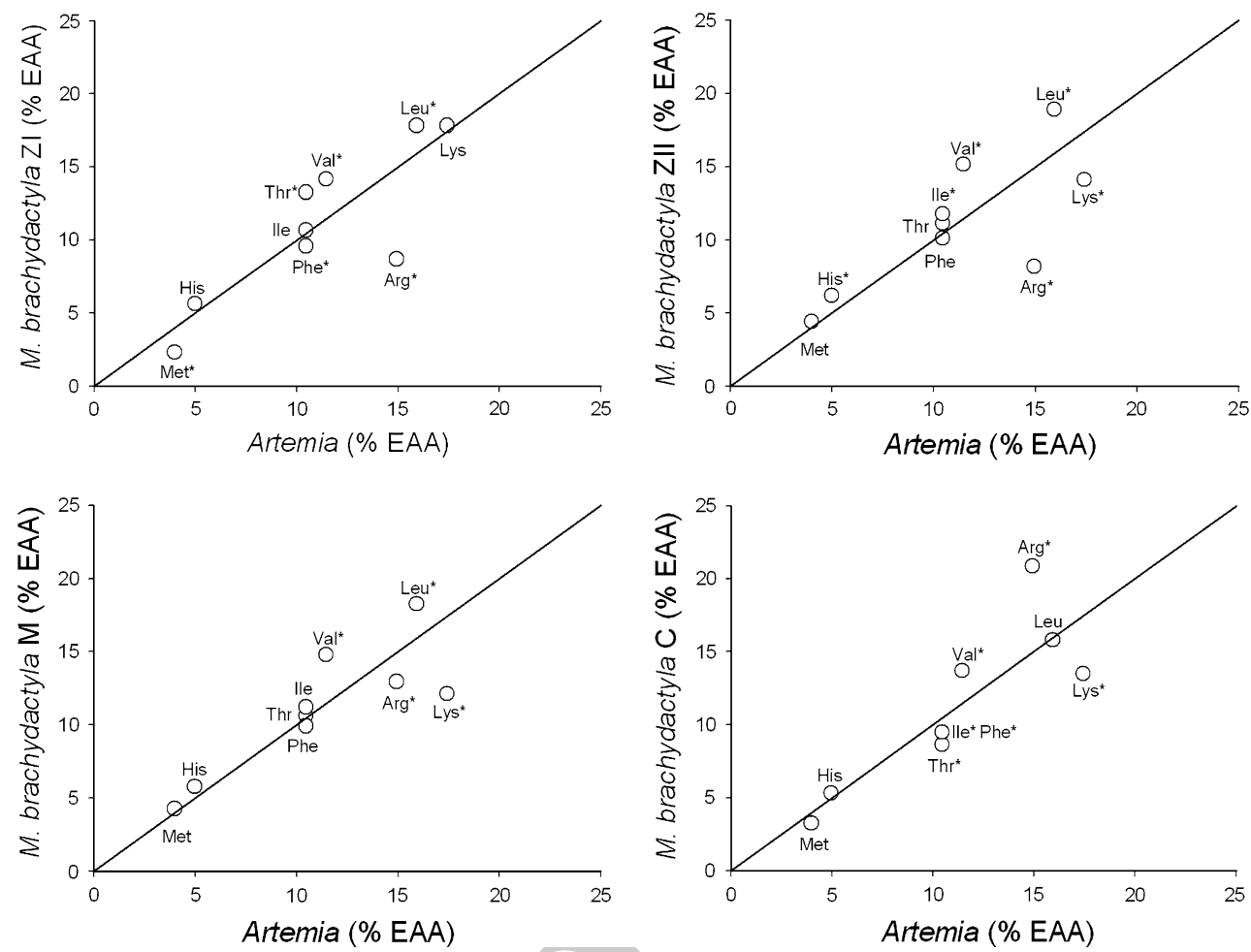

Table 4 Mineral content $\left(\mathrm{g} \mathrm{kg} \mathrm{DW}^{-1}\right)$ during larval development (zoea I $=$ ZI; zoea II $=$ ZII and megalopa $\left.=\mathrm{M}\right)$ and first juvenile stage $(\mathrm{C})$ of $M$. brachydactyla

\begin{tabular}{llllr}
\hline & ZI & ZII & M & C \\
\hline Macro elements & & & & \\
$\mathrm{Ca}$ & $92.21 \pm 8.54^{\mathrm{a}}$ & $82.33 \pm 4.28^{\mathrm{a}}$ & $93.86 \pm 1.34^{\mathrm{a}}$ & $173.94 \pm 6.46^{\mathrm{b}}$ \\
$\mathrm{Na}$ & $32.23 \pm 0.00^{\mathrm{c}}$ & $26.31 \pm 0.00^{\mathrm{b}}$ & $23.20 \pm 0.00^{\mathrm{a}}$ & $42.35 \pm 1.48^{\mathrm{d}}$ \\
$\mathrm{K}$ & $19.10 \pm 0.52^{\mathrm{c}}$ & $18.51 \pm 0.42^{\mathrm{c}}$ & $16.11 \pm 0.00^{\mathrm{b}}$ & $13.26 \pm 0.56^{\mathrm{a}}$ \\
$\mathrm{P}$ & $17.61 \pm 0.52^{\mathrm{b}}$ & $18.51 \pm 1.52^{\mathrm{b}}$ & $19.33 \pm 0.00^{\mathrm{b}}$ & $14.23 \pm 1.48^{\mathrm{a}}$ \\
$\mathrm{Mg}$ & $12.53 \pm 0.90^{\mathrm{a}}$ & $11.45 \pm 0.42^{\mathrm{a}}$ & $12.03 \pm 0.37^{\mathrm{a}}$ & $18.11 \pm 0.56^{\mathrm{b}}$ \\
$\mathrm{Trace} \mathrm{elements}$ & & & & \\
$\mathrm{Sr}$ & $0.430 \pm 0.04^{\mathrm{a}}$ & $0.429 \pm 0.004^{\mathrm{a}}$ & $0.423 \pm 0.007^{\mathrm{a}}$ & \\
$\mathrm{Fe}$ & $0.064 \pm 0.004^{\mathrm{b}}$ & $0.054 \pm 0.002^{\mathrm{a}}$ & $0.125 \pm 0.001^{\mathrm{d}}$ & $0.611 \pm 0.019^{\mathrm{b}}$ \\
$\mathrm{Cu}$ & $0.046 \pm 0.002^{\mathrm{b}}$ & $0.038 \pm 0.002^{\mathrm{a}}$ & $0.036 \pm 0.001^{\mathrm{a}}$ & $0.104 \pm 0.007^{\mathrm{c}}$ \\
$\mathrm{Mn}$ & $0.010 \pm 0.001^{\mathrm{ab}}$ & $0.009 \pm 0.000^{\mathrm{a}}$ & $0.013 \pm 0.001^{\mathrm{b}}$ & $0.040 \pm 0.002^{\mathrm{a}}$ \\
\hline
\end{tabular}

Data is shown as mean $\pm \mathrm{SD}$ (number of replicates: $n=3$, see "Sampling and biometric measurements" in text for details)

Different letters in superscript within the same row indicate significant differences among developmental stages (ANOVA, Holm-Sidak test, $P<0.05)$

development of $M$. brachydactyla indicates a good nutritional condition, allowing the larvae to be prepared to shortterm molts and metamorphosis (through the enhancement of TG reserves) and preparing the first juvenile to face future long-term periods of food scarcity (through $\mathrm{W}$ accumulation).

Sterols play a key role in growth, metabolic maintenance and in the regulation of regeneration and the molting cycle. Among these compounds, $\mathrm{CHO}$ is an essential precursor of vitamin D, steroid hormone and molting hormones (namely ecdysteroids) (Anger 2001). Larval decapods, together with other crustaceans, are incapable of de novo synthesis of sterols (Van der Oord 1964; Zande 1967; Whitney 1970) being CHO body levels derived from the diet (Ritar et al. 2003). In the present study, CHO levels were maintained around $22 \%$ of total lipids throughout the ontogeny of $M$. brachydactyla indicating that sterol requirements of the larvae and first juvenile of this species were fully covered by EA, containing $8.1 \%$ CHO. Phospholipids (PL) are important structural components of cell
401

402 403 404 405 406 407 408 409 410

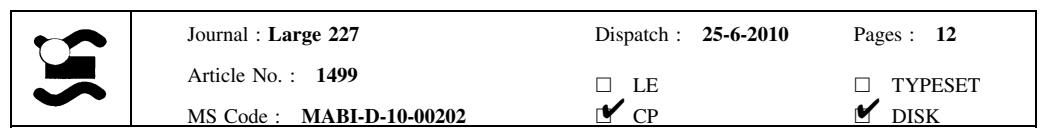


membranes acting as emulsifying agents in biologic systems. They play an active role in lipid transport from the hepatopancreas to the hemolymph and in the FA absorption within the body (Teshima et al. 1977). In general, polar lipids were present as a minor fraction, compared to neutral lipids, during $M$. brachydactyla ontogeny as it has been previously observed in other decapod species such as lobsters (Wickins et al. 1995). Enriched Artemia contains $1.6 \% \mathrm{PC}+\mathrm{PI}$ on a DW basis, which is within the range of fish and crustacean larval requirements (Coutteau et al. 1997) and, in the light of the results of the present study, this level might be enough to fulfill the PL requirements of spider crab larvae up to the first juvenile.

FA composition of $M$. brachydactyla newly hatched larvae (ZI) is in accordance with the FA profiles reported during its embryonic development by Figueiredo and Narciso (2008). Newly hatched larvae of M. brachydactyla contained, in absolute terms, lower content of FAs (30 $\mu \mathrm{g} \mathrm{mg} \mathrm{DW}^{-1}$ ) than eggs, as they were consumed throughout embryogenesis (28.58\% FA consumption from stage I to stage III-pre-hatching eggs). The main SFA reported in both eggs and larvae were 16:0 and 18:0. The proportions of these SFA were conserved from the embryo (11\% and 6\% of FA, respectively) (Figueiredo and Narciso 2008) to ZI, and along further larval and juvenile development $(\mathrm{C}=12 \%$ and $8 \%$ of $\mathrm{FA}$, respectively). No accumulation of SFAs in the larval body might indicate that these FAs, supplied in excess in the diet (EA), are consumed as an energy source throughout larval development. Significant amounts of odd-numbered SFA (mainly 15:0 and 17:0) have been reported (Figueiredo and Narciso 2008) during embryonic development of the spider crab. These FAs are known to be largely biosynthesized by marine heterotrophic bacteria, which are particularly abundant in the sediment (Volkman et al. 1998) and have been related to the detritivorous/scavenger nature common to crab species (Rosa et al. 2007). The absence of 15:0 and 17:0 in the larvae and juveniles of the present study might reflect the changes occurring in the alimentary habits of broodstock under captivity, where no sedimentary environment exists, in contrast to what occurs in the wild.

The main MUFA reserve in larvae and first juvenile of the spider crab was oleic acid (OA), which is the major FA in marine animals and a general marker for carnivory (Rosa et al. 2007). Figueiredo and Narciso (2008) found low OA content in M. brachydactyla eggs (8.7-11\% of FA), confirming the omnivorous diet described in sub-adults and adults for this species (Bernárdez et al. 2000, as Maja squinado). In the present study, OA increased significantly during larval development (9.8\% of FA in ZI to $22.2 \%$ of FA in C) reflecting both (1) the shift to a carnivorous diet of the broodstock maintained in captivity (fed on a mussel and crab basis) and (2) the higher degree of carnivorism observed during larval development which in turn derives from the ingestion of an OA-rich prey such as EA.

PUFA profiles of newly hatched larvae of M. brachydactyla resemble those reported for pre-hatching eggs of this species (Figueiredo and Narciso 2008). However, the beginning of the planktotrophic life implied a rapid and significant increase in linoleic (LA, from $1.2 \%$ of FA in ZI to $5.9 \%$ of FA in ZII) and linolenic acid (LNA, from $0.1 \%$ to $12.2 \%$ ) content in the tissues concomitant with a reduction in EPA (from $23.5 \%$ to $13.4 \%$ ) and DHA (from $15.1 \%$ to $5.7 \%$ of FA). This reduction might be explained either as a summative effect of the diet (EA contains $8.2 \%$ LA and $22.5 \%$ LNA) or by means of a retro-conversion from the highly unsaturated FA (HUFA, namely EPA and DHA) excess at hatching into $\mathrm{C}_{18}$ PUFA (LNA and LA). It seems unlikely that the relative reduction in HUFA $\omega-3$ (concomitant with a decrease in the $\omega-3 / \omega-6$ ratio) occurring after the onset of external feeding is due to a dietary deficiency, as Artemia enrichment provides significant amounts of these FAs. In addition, no significant changes occurred in the gravimetric $\left(\mu \mathrm{g} \mathrm{mg} \mathrm{DW}{ }^{-1}\right.$ ) content of both EPA and DHA in larval tissues from ZII onward (Table 2), suggesting that an active regulation of both FAs is occurring in order to maintain their levels constant in spite of the dietary input. In mud crab ( $S$. serrata) larvae, it has been suggested that a conversion of DHA to EPA and other FAs occurs when a dietary excess of DHA is provided (Suprayudi et al. 2004). Moreover, Artemia franciscana has been reported to retroconvert DHA into EPA when an excess of DHA is provided during the enrichment (Navarro et al. 1999). The same might be occurring along spider crab larval development, as confirmed by the increment in the EPA/DHA ratio.

Figueiredo and Narciso (2008) suggested that the high PUFA content (EPA and DHA) in spider crab eggs and the fact that they are significantly consumed during embryogenesis are indication for a high dietary PUFA requirement of larvae. According to the results of the present study, EA seems to provide adequate levels of PUFA to the larvae and first juvenile of $M$. brachydactyla. As it has been observed in previous studies with M. brachydactyla, enriched Artemia induces a faster larval development (Andrés et al. 2007), probably due to its high PUFA contribution. Similar results were obtained for $S$. serrata, in which an essential FA deficiency promoted lower survival rates and longer intermolt periods (Suprayudi et al. 2004).

Vitamin E (VE) is considered an essential dietary nutrient for crustaceans (Conklin 1997) with a well-known antioxidant function, very important for the prevention of lipid oxidation. Alpha-tocopherol (having the highest VE activity; He and Lawrence 1993; Lee and Shiau 2004) is degraded to protect PUFA against oxidation in larval fishes (Sargent et al. 1997). Thus, $\alpha$-tocopherol content is 
expected to be strongly correlated to PUFA content, as demonstrated in early stages of cephalopods by Villanueva et al. (2009). In their study, Villanueva and colleagues analyzed VE content of newly hatched larvae of M. brachydactyla, used as prey for cephalopod larviculture, obtaining similar values $\left(468.3 \pm 14.8 \mathrm{ng} \mathrm{mg} \mathrm{DW}^{-1}\right)$ to those reported in the present study. In spite of the great source of variation associated with our results, the decreasing trend observed in VE content from newly hatched larvae to ZII might be related to the degradation of $\alpha$-tocopherol associated with total PUFA content, which increased concomitantly to VE decrease, ranging from $14.0 \mu \mathrm{g}$ FA mg $\mathrm{DW}^{-1}$ in $\mathrm{ZI}$ to $18.5 \mu \mathrm{g} \mathrm{FA} \mathrm{mg} \mathrm{DW}{ }^{-1}$ in ZII.

Vitamin A (VA) levels in newly hatched larvae of $M$. brachydactyla have been recently analyzed by Villanueva et al. (2009), who found no retinol (ROL) in the spider crab ZI. The absence or low level of retinol observed in M. brachydactyla has been associated with the dynamics of carotenoids and VA in crustaceans. Some studies suggested that VA is not required in the early development of decapod crustaceans and its function is restricted to vision, with carotenoids taking its place in the early development (Dall 1995). In the present study, low but detectable levels of VA were found throughout M. brachydactyla ontogeny, with ROL being the main retinoid found along larval development, whereas the terminal oxidized form retinoic acid (RA) represented the main VA component in first juveniles. The irreversible nature of the retinoids' terminal oxidation step explains that RA shares only some of the activities of retinol. Thus, it is able to support growth and differentiation in most cell types, but it is unable to support the processes for which ROL or retinal (RAL) are specifically required and among them, some visual pigment effects that require RAL (Liñán-Cabello et al. 2002). Larvae of brachyuran crabs hatch with apposition eyes, which are similar to those of the adults (Anger 2001). During the course of development, more ommatidia are added and packed at an increasing density, simply enlarging the larval eye (Cronin and Jinks 2001). Therefore, it seems unlikely that the shift in retinoid dynamics of juveniles is associated with the ontogeny of vision, being a continuation of the larval morphology. On the other hand, RA has been found by Nemec et al. (1993) to inhibit metamorphosis in insects, acting as a juvenoid and having juvenile hormone ( $\mathrm{JH})$-like effects (Laufer and Biggers 2001). Many studies have demonstrated the presence of an analog of $\mathrm{JH}$-like in crustaceans, namely methyl farnesoate (MF) (Rotllant et al. 2000; Laufer et al. 2002; Nagaraju 2007), which has important roles in the physiology of both larvae and adult crustaceans. Whether RA act as an analog to MF in the control of morphogenesis of decapod juveniles, as occurs in insects, is yet to be revealed, but might explain the high levels of RA found in first juveniles of M. brachydactyla.
The amino acid profile (AA) of newly hatched larvae of $M$. brachydactyla described here is in agreement with the results reported by Villanueva et al. (2004) where Glu is the major AA found in the spider crab ZI. However, some differences were found between the two studies, with Ala and Gly representing the second and third main AA of ZI in the present work, whereas Lys and Pro take these positions in Villanueva and colleagues study. Due to the little knowledge concerning AA dynamics and requirements in brachyuran larvae (reviewed by Anger 2001), it remains unclear whether the variation in the AA profile between these studies indicates the different origin of the broodstock (wild vs captive) or might reflect certain deficiencies in the diet of captive adult specimens of M. brachydactyla. In the present study, Glu was maintained as the major AA throughout spider crab development, followed by Ala and Gly at early stages. As ontogeny advanced, Gly content decreased concomitant with a remarkable increase in Arg. A strong correlation between the EAA in the diet and in the whole body tissues has been cited in crustacean nutritional studies (Guillaume 1997). However, Peñaflorida (2004) found no relationships between the lack of certain AA in the diet and their presence in the female ovary, eggs or zoeas of the mud crab, S. serrata. Larvae of M. brachydactyla seemed to adjust their initial Thr levels to those found in their prey, whereas other EAA such as Val and Leu were kept high in the larvae, despite their apparent deficiency in the live food (Fig. 2). The EAA profile shifted from an early major content on Lys to a dramatic increase in Arg at later larval stages and first juvenile. Such variations seem to be independent of larval diet, since EA contains higher levels of Lys than Arg (Villanueva et al. 2004). However, this observation should be taken with caution, as the Artemia amino acid profiles reported by Villanueva and colleagues are not necessarily identical to our Artemia amino acid profiles. In addition, Gly, Arg, Glu, Ala and Pro have been reported as the most abundant AA in adult M. brachydactyla muscle (Camien et al. 1951, as Maia squinado) resembling the profile found in the juveniles of the present study. The role of these AA is crucial, since Arg, Ala and Gly are known to maintain glycolysis under hypoxic conditions, whereas both Ala and Pro are involved in the intracellular isosmotic regulation (for references, see Brucet et al. 2005). Future studies might reveal whether the Artemia deficiency in Arg would affect $M$. brachydactyla further development after metamorphosis, considering the need to find a more balanced diet for juveniles. Non-essential AA showed higher variability during development with a decrease in Glu after metamorphosis into juvenile and peaks in Pro and Arg content in ZII. In juveniles of Norway lobster, $N$. norvegicus, an increase in protein-bound Arg and Pro in muscle was accompanied by an increase in RNA and protein contents 
being associated with a higher synthetic activity (Rosa and Nunes 2003).

In aquatic animals, minerals may serve as components of hard-tissue matrices, soft tissues and as cofactors and/or activators of a variety of enzymes. The more soluble minerals ( $\mathrm{Ca}, \mathrm{P}, \mathrm{Na}$ and $\mathrm{K}$ ) also function in osmoregulation and in the maintenance of both the acid-base balance and membrane potentials (Davis and Lawrence 1997). Macro elements such as $\mathrm{Ca}, \mathrm{Mg}, \mathrm{Na}$ and $\mathrm{K}$ can be taken up directly from the surrounding water across the epithelia of the gill chamber and the intestine, and hence they are considered non limiting factors for aquatic decapods living in the marine environment (Anger 2001). Variations in non-essential minerals (Ca, $\mathrm{Na}, \mathrm{K}$ and $\mathrm{Mg}$ ) during $M$. brachydactyla ontogeny might be a consequence of morphological and physiologic changes in larvae and juveniles such as the formation of carapace and the maintenance of the osmotic balance. Larval requirements in essential minerals (such as $\mathrm{P}, \mathrm{Cu}, \mathrm{Fe}$ and $\mathrm{Mn}$ ) seem to be fully covered by EA, the mineral content of which has been previously reported by Villanueva and Bustamante (2006). However, a significant decrease in the $\mathrm{P}$ content found in the juveniles after metamorphosis might indicate a dietary deficiency and the need to find other food items (prey or artificial diets) richer in $\mathrm{P}$ for juvenile feeding. The remarkably high content of $\mathrm{Sr}$ in $M$. brachydactyla larvae might be associated with carapace calcification and thus explain the high amounts found in juveniles.

In conclusion, larvae of $M$. brachydactyla fed with enriched Artemia are, in general, in a good nutritional condition as confirmed by the continuous lipid store accumulation (TAG and W) throughout their ontogeny. Phospholipids, cholesterol and PUFA requirements for an adequate larval development seem to be fully supplied by an enriched Artemia diet. Broodstock maintenance in captivity and, as a consequence, the shift from a wild into a captive diet may have had direct consequences in newly hatched larval biochemical composition, especially in terms of SFA and MUFA. A strong regulation of PUFA is occurring throughout spider crab larval development in order to maintain adequate basal levels of HUFA $\omega-3$ (likely through a retro conversion of EPA and DHA into PUFA). In general, variations in the essential amino acid balance, fat-soluble vitamins and mineral content during larval development of $M$. brachydactyla are not related with the Artemia feeding regime, but rather with the species ontogeny. The study of the essential biochemical components of spider crab larvae shows that a proper nutrient input promotes an adequate growth and larval success at molting, preparing for the future juvenile and adult life.

Acknowledgments Thanks to the financial support provided by the Ministry of Science and Innovation of Spain to MA (INIA predoctoral fellowship) and to GR (INIA project RTA-2005-00022). The authors would like to thank O. Bellot, N. Gras, M. Sastre, G. Macià and M. Monllaó for their help as hatchery and laboratory technicians at IRTA, Sant Carles de la Ràpita.

\section{References}

Andrés M, Estévez A, Rotllant G (2007) Growth, survival and biochemical composition of spider crab Maja brachydactyla (Balss, 1922) (Decapoda: Majidae) larvae reared under different stocking densities, prey: larva ratios and diets. Aquaculture 273:494-502

Andrés M, Estévez A, Anger K, Rotllant G (2008) Developmental patterns of larval growth in the edible spider crab, Maja brachydactyla (Decapoda: Majidae). J Exp Mar Biol Ecol 357:35-40

Anger K (2001) The biology of Decapod Crustacean larvae. A.A Balkema Publishers, Lisse

AOAC (2005a) Official Method 945.04: Calcium (acid soluble) in fertilizers. In: Horwitz W (ed) The official methods of analysis, 18 th edn. AOAC International, Gaithersburg

AOAC (2005b) Official method 958.01: phosphorus (total) in fertilizers. In: Horwitz W/(ed) Official methods of analysis, 18th edn. AOAC International, Gaithersburg

AOAC (2005c) Official method 969.23: sodium and potassium in seafood. In: Horwitz W (ed) Official methods of analysis, 18th edn. AOAC International, Gaithersburg

AOAC (2005d) Official method 972.02: manganese (acid-soluble) in fertilizers. In: Horwitz W (ed) Official methods of analysis, 18th edn. AOAC International, Gaithersburg

AOAC (2005e) Official method 975.01: copper in fertilizers. In: Horwitz W (ed) Official methods of analysis, 18th edn. AOAC International, Gaithersburg

AOAC (2005f) Official method 975.03: metals in plants and pet foods. In: Horwitz W (ed) Official methods of analysis, 18th edn. AOAC International, Gaithersburg

AOAC (2005g) Official method 980.01: iron in fertilizers. In: Horwitz $\mathrm{W}$ (ed) Official methods of analysis, 18th edn. AOAC International, Gaithersburg

Auel H, Harjes M, da Rocha R, Stubing D, Hagen W (2002) Lipid biomarkers indicate different ecological niches and trophic relationships of the Arctic hyperiid amphipods Themisto abyssorum and T. libellula. Polar Biol 25:374-383

Balss H (1922) Crustacea VII: Decapoda Brachyura (Oxyrhyncha und Brachyrhyncha) und geographische Übersicht über Crustacea Decapoda. In: Michaelsen W (ed) Beiträge zur Kenntnis der Meeresfauna Westafrikas. Friederichsen and Co., Hamburg, pp 69-110

Bernárdez C, Freire J, González-Gurriarán E (2000) Feeding of the spider crab Maja squinado in rocky subtidal areas of the Ria de Arousa (north- west Spain). J Mar Biol Assoc UK 80:95-102

Brucet S, Boix D, López-Flores R, Badosa A, Quintana XD (2005) Ontogenetic changes of amino acid composition in planktonic crustacean species. Mar Biol 148:131-139

Camien MN, Sarlet H, Duchateau G, Florkin M (1951) Non-protein amino acids in muscle and blood of marine and fresh water crustacea. J Biol Chem 193:881-885

Christie WW (1982) Lipid analysis: isolation, separation, identification, and structural analysis of lipids. Pergamon, New York

Conklin DE (1997) Vitamins. In: D'Abramo LR, Conklin DE, Akiyama DM (eds) Crustacean nutrition, advances in world aquaculture. The World Aquaculture Society, Baton Rouge, pp 123-149

Coutteau P, Geurden I, Camara MR, Bergot P, Sorgeloos P (1997) Review on the dietary effects of phospholipids in fish and crustacean larviculture. Aquaculture 155:149-164 
Cronin TW, Jinks RN (2001) Ontogeny of vision in marine crustaceans. Am Zool 41:1098-1107

Dall W (1995) Carotenoids versus retinoids (vitamin A) as essential growth factors in penaeid prawns (Penaeus semisulcatus). Mar Biol 124:209-213

Davies MG, Thomas AJ (1973) An investigation of hydrolytic techniques for the amino acid analysis of foodstuffs. J Sci Food Agric 24:1525-1540

Davis DA, Lawrence AL (1997) Minerals. In: D'Abramo LR, Conklin DE, Akiyama DM (eds) Crustacean nutrition, advances in world aquaculture. The World Aquaculture Society, Baton Rouge, pp 150-163

Figueiredo J, Narciso L (2008) Egg volume, energy content and fatty acid a profile of Maja brachydactyla (Crustacea: Brachyura: Majidae) during embryogenesis. J Mar Biol Assoc UK 88:14011405

Folch J, Lees M, Sloane Stanley GH (1957) A simple method for the isolation and purification of total lipides from animal tissues. J Biol Chem 226:497-509

Fraser AJ (1989) Triacylglycerol content as a condition index for fish, bivalve, and crustacean larvae. Can J Fish Aquat Sci 46:18681873

Ghioni C, Porter AEA, Taylor GW, Tocher DR (2002) Metabolism of 18: $4 \mathrm{n}-3$ (stearidonic acid) and 20: $4 \mathrm{n}-3$ in salmonid cells in culture and inhibition of the production of prostaglandin F-2 alpha (PGF(2 alpha)) from 20: 4n-6 (arachidonic acid). Fish Physiol Biochem 27:81-96

Guerao G, Pastor E, Martin J, Andres M, Estevez A, Grau A, Duran J, Rotllant G (2008) The larval development of Maja squinado and M. brachydactyla (Decapoda, Brachyura, Majidae) described from plankton collected and laboratory-reared material. J Nat Hist 42:2257-2276

Guerao G, Rotllant G, Anger K (2010) Characterization of larval moulting cycles in Maja brachydactyla (Brachyura, Majidae) reared in the laboratory. Aquaculture 302:106-111

Guillaume J (1997) Protein and amino acids. In: D'Abramo LR, D'Abramo LR, Akiyama DM (eds) Crustacean nutrition, advances in world aquaculture. The World Aquaculture Society, Baton Rouge, pp 26-50

Harvey EA, Epifanio CE (1997) Prey selection by larvae of the common mud crab Panopeus herbstii Milne edwards. J Exp Mar Biol Ecol 217:79-91

He H, Lawrence AL (1993) Vitamin E requirement of Penaeus vannamei. Aquaculture 118:245-255

Laufer H, Biggers WJ (2001) Unifying concepts learned from methyl farnesoate for invertebrate reproduction and post-embryonic development. Am Zool 41:442-457

Laufer H, Ahl J, Rotllant G, Baclaski B (2002) Evidence that ecdysteroids and methyl farnesoate control allometric growth and differentiation in a crustacean. Insect Biochem Mol Biol 32:205-210

Lee MH, Shiau SY (2004) Vitamin E requirements of juvenile grass shrimp, Penaeus monodon, and effects on non-specific immune responses. Fish Shellfish Immunol 16:475-485

Liñán-Cabello MA, Paniagua-Michel J, Hopkins PM (2002) Bioactive roles of carotenoids and retinoids in crustaceans. Aquac Nutr 8:299-309

Nagaraju GPC (2007) Is methyl farnesoate a crustacean hormone? Aquaculture 272:39-54

Navarro JC, Henderson RJ, McEvoy LA, Bell M, Amat F (1999) Lipid conversions during enrichment of Artemia. Aquaculture 174:155-166

Nemec V, Kodrík D, Matolín S, Laufer H (1993) Juvenile hormone-like effects of retinoic acid in insect metamorphosis, embryogenesis and reproduction. J Insect Physiol 39:10831093
Olsen RE, Henderson RJ (1989) The rapid analysis of neutral and polar marine lipids using double-development HPTLC and scanning densitometry. J Exp Mar Biol Ecol 129:189-197

Ouellet P, Taggart T, Frank KT (1992) Lipid condition and survival in shrimp (Pandalus borealis) larvae. Can J Fish Aquat Sci 49:368378

Peñaflorida VD (2004) Amino acid profiles in the midgut, ovary, developing eggs and zoea of the mud crab, Scylla serrata. Isr J Aquacult Bamidgeh 56:113-125

Pfeifer R, Karol R, Korpi J, Burgoyne R, McCourt D (1983) Practical application of HPLC to amino-acid analysis. Am Lab 15:77-84

Rengel J, Rosas J, Cabrera T, Millan J, Leon L (2000) Efecto de dietas en la sobrevivencia de Mithrax spinosissimus. 51st Gulf and Caribbean Fisheries Institute, pp 324-329

Ritar AJ, Dunstan GA, Crear BJ, Brown MR (2003) Biochemical composition during growth and starvation of early larval stages of cultured spiny lobster (Jasus edwarsii) phyllosoma. Comp Biochem Physiol Part A Mol Integr Physiol 136:353-370

Rosa R, Nunes ML (2003) Seasonal changes in nucleic acids, amino acids and protein content in juvenile Norway lobster (Nephrops norvegicus). Mar Biol 143:465-572

Rosa R, Calado R, Narciso L, Nunes ML (2007) Embryogenesis of decapod crustaceans with different life history traits, feeding ecologies and habitats: a fatty acid approach. Mar Biol 151:935947

Rotllant G, Takac P, Liu L, Scott GL, Laufer H (2000) Role of ecdysteroids and methyl farnesoate in morphogenesis and terminal moult in polymorphic males of the spider crab Libinia emarginata. Aquaculture 190:103-118

Sargent JR (1976) The structure, metabolism and function of lipids in marine organisms. Biochem Biophys Perspect Mar Biol 3:149 212

Sargent JR, McEvoy LA, Bell JG (1997) Requirements, presentation and sources of polyunsaturated fatty acids in marine fish larval feeds. Aquaculture 155:117-127

Suprayudi MA, Takeuchi T, Hamasaki K (2004) Essential fatty acids for larval mud crab Scylla serrata:implications of lack of the ability to bioconvert $\mathrm{C} 18$ unsaturated fatty acids to highly unsaturated fatty acids. Aquaculture 231:403-416

Takeuchi T, Dedi J, Haga Y, Seikai T, Watanabe T (1998) Effect of vitamin A compounds on bone deformity in larval Japanese flounder (Paralichthys olivaceus). Aquaculture 169:155-165

Takeuchi T, Satoh N, Sekiya S, Shimizu T, Watanabe T (1999) The effect of dietary EPA and DHA on the molting rate of larval swimming crab Portunus trituberculatus. Nippon Suisan Gakkai Shi 65:998-1004

Teshima S, Kanazawa A, Okamoto H (1977) Variation in lipid classes during the molting cycle of the prawn Penaeus japonicus. Mar Biol 39:129-136

Urcera M, Arnaiz R, Rua N, Coo A (1993) Cultivo de la centolla Maja squinado: Influencia de la dieta en el desarrollo larvario. In: Actas IV Congreso Nacional Acuicultura, pp 269-274

Van der Oord A (1964) The absence of cholesterol synthesis in the crab, Cancer pagurus L. Comp Biochem Physiol 13:461-467

Villanueva R, Bustamante P (2006) Composition in essential and nonessential elements of early stages of cephalopods and dietary effects on the elemental profiles of Octopus vulgaris paralarvae. Aquaculture 261:225-240

Villanueva R, Riba J, Ruíz-Capillas C, González AV, Baeta M (2004) Amino acid composition of early stages of cephalopods and effect of amino acid dietary treatments on Octopus vulgaris paralarvae. Aquaculture 242:455-478

Villanueva R, Escudero JM, Deulofeu R, Bozzano A, Casoliva C (2009) Vitamin A and E content in early stages of cephalopods and their dietary effects in Octopus vulgaris paralarvae. Aquaculture 286:277-282 
Volkman JK, Barrett SM, Blackburn SI, Mansour MP, Sikes EL, Gelin F (1998) Microalgal biomarkers: a review of recent research developments. Org Geochem 29:1163-1179

Whitney JO (1970) Absence of sterol biosynthesis in the blue crab Callinectes sapidus Rathbum and in the barnacle Balanus nubilus Darwin. J Exp Mar Biol Ecol 4:229-237
Wickins JF, Beard TW, Child AR (1995) Maximizing lobster, Homarus gammarus (L.), egg and larval viability. Aquac Res 26:379-392

Zande DI (1967) Absence of cholesterol synthesis as contrasted with the presence of fatty acid synthesis in some arthropods. Comp Biochem Physiol 20:811-822
875

876

877

878

879

880

881 